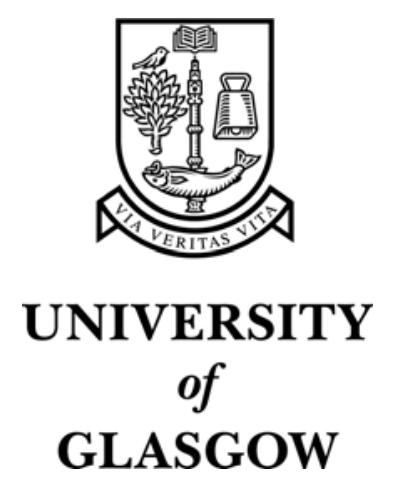

Clayton, P. (2000) Was it worth it? A comparison of the role of adult education and training in the labour market insertion and progress of men and women in the West of Scotland: results of qualitative research. International Journal of Lifelong Education 19(3):pp. 199-214.

http://eprints.gla.ac.uk/2827/ 


\title{
Was it worth it? \\ Gender boundaries and the role of adult education in labour market progress
}

\author{
Pamela Clayton
}

\section{Published in 'International Journal of Lifelong Learning' 2000}

\begin{abstract}
Despite a number of relevant longitudinal studies carried out in Sweden, Finland, Norway and the United States of America, there is a relative paucity of research into the long-term outcomes of adult return to learning. This paper uses data from the first survey in Scotland into the long-term outcomes of adult learning (in this case, formal education/training) in order to explore the potential of adult learning for enhancing social citizenship, by facilitating labour market insertion and progress. The paper focuses particularly on an analysis of gender patterns. The issues addressed are: the extent to which respondents expected participation in adult education to benefit them in the labour market; whether labour-market-orientated participation in adult education brought positive occupational outcomes; the extent to which unintended labour market outcomes arose from participation in adult education; how women who undertook adult education did in labour market terms compared to men; to what extent personal perception of labour market progress was related to income; the kind of adult education which appeared to bring the most beneficial labour market outcomes; and any differences between men and women in this respect; and finally, the extent to which adult education appeared to promote greater social citizenship.
\end{abstract}

\section{Long-term outcomes of adult education}

Participation in adult education involves a significant commitment on the part of the individual in terms of investment of time, financial resources and personal risk. From a societal point of view, adult education involves an allocation of scarce resources - both public and private. It is rather surprising, therefore, that there is a relative paucity of research which is available on the outcomes of adult participation in education. There is a tendency amongst those involved with adult education to assume 
intended effects (Bergman 1993:38). Rogers (1992) further points out the need to assess achievements which may appear after, in some cases long after, a course has finished. An analysis of the labour market outcomes of adult education is not only in the interest of policy-makers and educational providers, but preeminently in the interests of those who invest time and money and sometimes jeopardise personal relationships (Calder 1993:134) in order to attain a specific object - the students themselves. This becomes even more significant when adult education is looked to as a way of enhancing the socio-economic status of marginalised groupings (Rinne \& Kivinen 1993).

Despite this relative 'dearth of studies of outcomes in terms of subsequent occupational status' (Gooderham 1991:203), there has been a number of relevant longitudinal studies and surveys. For example, Ashenfelter \& Card (1985) studied the outcomes of training programmes for unemployed and low-income workers in the USA between 1970 and 1978, collating data for a total of 9,837 trainees plus a control group. Tuijnman (1986) used quantitative data collected between 1938 and 1988 for 834 men in Malmö, Sweden, in one of the few longitudinal studies of the outcomes of adult education, albeit only on men. Fermlee (1988) used data from the U. S. National Longitudinal Survey of Labour Market Experience of Young Women (1968-73), which sampled white and black women aged 14-24 from the civilian noninstitutionalised population and reinterviewed them annually. Gooderham (1991), in a social mobility study, surveyed a sample of 350 Norwegian adults who had all left full-time education for the labour market before taking Higher Secondary Education (HSE) courses (four of which are necessary for university entrance) on a part-time basis. Rinne \& Kivinen (1993) carried out 3,990 interviews in 1990 with a representative sample of the adult population of Finland in order to evaluate the impact of 'second chance education'. Farnes (1993) collected life histories from a random sample of 60 women who had completed Open University Community Education courses in Glasgow two years previously. Mikkonen (1996), in an ongoing study, surveyed through postal questionnaires 5,000 participants in labour market training in Finland and a control group of job-seekers. Finally, there was a follow-up of people who had graduated from Scottish 
universities four years previously, in 1992; but unfortunately, no detailed analysis was made of the 242 graduates who had begun their first degree at the age of 21 or over (Levey \& Mackenzie 1996).

\section{Adult education, the labour market and social citizenship}

A concept which has long been generating discussion is that of social citizenship, and part of this discussion concerns the role of education and training in accomplishing this goal (Janne et al 1980;

Duke 1992; Heaney 1992; Gelpi 1994; European Commission 1997). The concept is not unproblematic: citizenship is a relatively undeveloped concept within many states. Since the 19th century, citizenship has commonly been linked to the franchise, and today an adult citizen of a nationstate is seen as one with the right to vote in that state. Given, though, the widespread model of representative rather than popular or truly participative democracy that predominates in Europe, this is clearly a minimal definition. Hence, the idea of social citizenship is perhaps more germane. This involves real democratic participation, with every citizen having the same entitlements and responsibilities, and presupposes a broad doctrine of collective responsibility for social problems. Thus social citizenship is inclusive.

The development of welfare states from the early twentieth century onwards can be seen as an attempt to translate political equality into social citizenship, first for men and later for women. The culmination of this idea in the United Kingdom was the 'Beveridge Report' (1942), which proposed a system of social insurance to provide a safety-net to which citizens were entitled, 'from the cradle to the grave'. Beyond this, Beveridge (1944) also saw the elimination of poverty requiring the provision of health, education (including lifelong learning), culture and labour policies providing full employment. Pateman (1989:10) has argued, however, that possession of the franchise and the existence of the welfare state have not given women (or all men) full and effective citizenship: 'Paid employment has become the key to citizenship, and the recognition of an individual as a citizen of equal worth to other citizens is lacking when a worker is unemployed'. 
'Social purpose' adult education has a long history (Fieldhouse 1993), but several questions for adult educators arise from the implicit conflation of 'citizenship' and 'work'. Does adult education make a contribution to the promotion of social citizenship through supporting labour market insertion and progress? Does it, in fact, help individuals who wish to improve their chances in the labour market? Are 'vocational' courses the most valuable for labour market progress? Does women's relatively precarious relationship to the labour market adversely affect feelings of inclusion?

We would argue that labour market participation and career advancement may be the outcomes of a wide range of courses. The broad questions addressed in this paper, then, are these: is there any evidence that adult education positively affects social citizenship, as defined in the above way? What, if any, role does it appear to play in relation to breaking down gender boundaries?

\section{Background to the research}

The data presented here are taken from qualitative research funded by the Scottish Higher Education Funding Council (SHEFC) into the long-term outcomes of adult education. This is the first study in Scotland of the long-term outcomes of adult return to education. The term 'adult education' is used here to include all learning undertaken in formal institutions, including the workplace, thus avoiding the 'unhelpful dichotomy' between education and training (Bell 1996:152). It does not include all forms of adult 'learning', which often goes on informally and is not necessarily recognised by the learner as ‘learning' (Calder 1993; Sargent 1996).

The total sample was drawn from adults who, five or six years previously, had participated in an education programme. As one of the main objectives of the study was to examine the extent to which outcomes related to the programme attended, the sample was designed to include interviewees drawn from a spectrum of different types of courses. Variables included the explicit emphasis placed on labour market related outcomes and on academic progression. As a result interviewees were drawn from those who had attended (a) employer-provided occupational training; (b) access programmes 
(provided both by a university and through colleges of further education which ran the Scottish Wider Access Programme (SWAP)); (c) liberal adult education courses provided by a university and by the Workers Educational Association (WEA); (d) community-based educational courses provided by local authorities; and (e) school-based programmes (where adults study along with young people). Interviewees turned out to have taken a range of courses in addition to the one for which they were selected.

The value of this study, we believe, lies in the data gained from people reflecting back over time and evaluating the role of adult education in their lives. Life history interviews (recorded verbatim) were conducted with 105 people between 1993 and 1996. This paper focuses on the 74 who were in the labour market (including 10 unemployed), in order to evaluate the impact of adult education on economic outcomes. It thus excludes those who had permanently or temporarily left the labour market through age, disability, full-time study, domestic responsibilities or inclination. Labour market 'success' is here defined as (re)entering the labour market, finding a better job, obtaining promotion or improving performance in a job. Labour market 'failure' is defined as failure to find a job, failure to find a job meeting career aspirations or finding only a short-lived job. The preliminary qualitative findings are being tested against information from large-scale datasets.

The research was carried out in one of the most deprived regions of Scotland, the area covered by the former Strathclyde Regional Council and whose nucleus is the City of Glasgow. Of those in employment in Scotland, 45 per cent $(156,000$ out of 347,000) live in Strathclyde (Office for National Statistics 1995). There are several indicators of relative poverty. Strathclyde has higher death rates, including perinatal and infant mortality, than the United Kingdom average or the Scottish Regions as a whole. It also has higher unemployment and lower than average gross weekly full-time earnings, leading to lower household and disposable income. Women fare particularly badly. Although women employed full-time in Strathclyde earned 73.8 per cent of male earnings, slightly better than in the UK (72 per cent) and Scotland (72.7 per cent) as a whole, this hardly improves their position, and those 
with children under school age are likely to have to pay for child care. The shortage of state provision is particularly serious for lone parents. Live births outside marriage, which have more than doubled between 1981 and 1993 in the country as a whole, are higher than average in Strathclyde at 34 per cent. Although many of these births are to couples in stable relationships, there is a high rate of lone parenthood, mainly motherhood: a third of Glasgow households containing children are headed by lone parents.

The interviewees in this study comprise 31 men and 43 women either in paid (self)employment or seeking paid employment at the time of the interview. Five of the men and five of the women were unemployed. In some ways, the group reflects general patterns: men in employment overwhelmingly work full-time, whereas just over half the women work part-time, with a low rate of self-employment for both sexes. A higher proportion of men than women were unemployed and seeking work (Labour Force Surveys ${ }^{1}$ in the 1990 s show few changes in these respects). What is not typical is that the men and women employed full time earned the same median net weekly income (£250-299); it is tempting to speculate that this is the effect of adult education, though this cannot be confirmed without reference to large-scale quantitative data (for a more quantitative consideration of employment and adult education, see Clayton and Slowey 1996).

The analysis comprises the following: economic intentions and economic outcomes; 'successful' economic outcomes; subjective versus objective views of labour market 'success'; 'unsuccessful' economic outcomes; and the role of qualifications in labour market 'success'.

\footnotetext{
1 The Labour Force Survey conducted by the Department for Education and Employment questions 60,000 households each quarter about labour market issues and publishes data on, for example, unemployment, earnings and hours, part-time and full-time work, and the labour market position of women, ethnic minorities and disabled people.
} 


\section{Labour market outcomes}

\section{Economic intentions and economic outcomes}

Interviewees were asked their reasons for participating in adult education and what they had hoped to gain from it. Responses certainly illustrated the common finding that 'students are likely to have multiple objectives through which they hope to achieve both short term and longer term aims' (Calder 1993:128, and see also Munn \& MacDonald 1988). In Table 1, the categorisation, therefore, abstracts the extent to which adult education was initially seen by interviewees in terms of labour market outcomes, together with the actual outcome. The first category consists of those whose motivation for adult education was purely expressive or oriented in other directions, such as voluntary work, and who did not find any labour market outcomes as a by-product. The second consists of those who undertook adult education in order to improve their labour market position but were disappointed by the results. The third consists of those who had obtained the desired labour market outcomes through their return to adult education. The fourth consists of those who returned to learning for purely expressive reasons but found unexpected beneficial labour market outcomes.

Table 1. Motivation for adult participation in education and labour market outcomes, by sex and employment status at time of interview $(n=74)$

\begin{tabular}{|l|c|c|c|c|c|}
\hline & $\begin{array}{c}\text { Employed } \\
\text { men }\end{array}$ & $\begin{array}{c}\text { Unemployed } \\
\text { men }\end{array}$ & $\begin{array}{c}\text { Employed } \\
\text { women }\end{array}$ & $\begin{array}{c}\text { Unemployed } \\
\text { women }\end{array}$ & Totals \\
\hline $\begin{array}{l}\text { No labour market outcomes } \\
\text { intended or obtained }\end{array}$ & 3 & 1 & 6 & 2 & 12 \\
\hline $\begin{array}{l}\text { Beneficial labour market } \\
\text { outcomes as intended }\end{array}$ & 22 & 0 & 14 & 1 & 37 \\
\hline $\begin{array}{l}\text { Failed to meet labour market } \\
\text { hopes/expectations }\end{array}$ & 0 & 4 & 3 & 2 & 9 \\
\hline $\begin{array}{l}\text { Unexpected labour market } \\
\text { outcomes }\end{array}$ & 1 & 0 & 15 & 0 & 16 \\
\hline & 26 & 5 & 38 & 5 & 74 \\
\hline
\end{tabular}

Although the starting-point here is on the economic 'worth' of the experience, a significant number of interviewees, mainly women, reported that they returned to education, at least initially, for non-labour 
market reasons; but some of these found unexpected labour market outcomes and/or went on to take courses with the labour market in mind.

The motivations of 62 per cent of interviewees, however ( 46 per cent of the women and 84 per cent of the men), included improving labour market position. This is higher than the 48 per cent recorded in the 1996 NIACE/Gallup Survey on Lifelong Learning (Tuckett \& Sargant 1996), but this is to be expected, given that this subgroup of our sample involves only individuals who were in the labour market. The Individual Commitment to Learning (ICTL) survey carried out in England in 1993 found that 48 per cent of its total sample but 63 per cent of its employed sample were 'learners' (Park 1994). The gender differences reflect the findings of a major study of adult participation in education and training in Scotland: 'vocational purposes are dominant for men ... more women than men return for personal interest' (Munn \& MacDonald 1988:10). Furthermore, 22 of the 31 men but only 12 of the 43 women had taken all of their courses at least partly in order to improve their labour market position. The women were more likely to have taken some courses for pleasure as well as for profit.

In this sample, only a minority reported no labour market outcomes, whether hoped-for or not. The biggest group, 53, felt that they had benefited in the labour market from adult education, whatever their initial motivation. Of these, 15 women and 1 man had done so without prior intention or expectation of doing so. This is similar to McGivney's (1995) finding that participation in liberal education had resulted in a number of interviewees using their newly acquired knowledge or skills in their current employment or even making a complete career change, while some unemployed students had found jobs. Farnes (1993) found that about 40 per cent of his sample had taken up employment after their course and some said the courses were useful in getting a job; but there is no data on the type of employment they found.

Employed interviewees were also asked for their reasons for being in paid employment, in order to examine the relationship between instrumental and expressive motivations for paid work and for adult 
education. Suggested instrumental responses were: 'to follow my career' (this is not to discount the expressive element in such a desire); 'need money for basic essentials'; and 'to earn money to buy extras'. Other choices were: 'working is the normal thing to do'; 'to earn money of my own'; 'for the company of other people'; 'enjoy working'; and 'other'.

Women were more likely than men to include non-economic reasons, including 'working is the normal thing to do', 'enjoy working' and 'other reasons' such as 'I love working with children'; 'to prove I can contribute something worthwhile'; 'to develop myself'; and 'to stretch myself'. The single most important main reason for both sexes, however, was 'to buy basic essentials' (18 out of 31 men and 15 out of 43 women). Of the women who gave this as their main reason for employment, 11 were sole earners or women in households where the total net income was relatively low or the husband was unemployed or at risk of unemployment. One married women explained:

I'm afraid I have to say 'to earn money for basic essentials', and that's a definite, and it's not really for extras, it is for the basic - I'm sorry to say, I hate to admit it ... I do enjoy the company of other people but that's not the reason I went out to work. I think it's basically the money (part-time clerical assistant).

Furthermore women working full-time were as likely to be working 'to follow my career' - 10/16 (62 per cent) as men working full time - 14/22 (64 per cent), and five part-time female employees also gave this reason. There was thus some convergence between men and women in terms of the economic necessity for paid employment and career orientation.

It might be expected that people with economic motivations for employment might use adult education primarily to enhance their labour market position. Table 2 summarises the relationship between economic motivations for employment with motivation for returning to or continuing in education as adults. 
Table 2. Motivation for participation in adult education among male and female interviewees who were in employment $(\mathrm{n}=64)$

\begin{tabular}{|l|c|c|}
\hline & \multicolumn{2}{|c|}{$\begin{array}{c}\text { To follow my career; to earn money } \\
\text { for basic essentials; and/or to earn } \\
\text { money to buy extras }\end{array}$} \\
\hline & Men & Women \\
\hline $\begin{array}{l}\text { No labour market motive for adult } \\
\text { education at any time }\end{array}$ & 4 & 6 \\
\hline $\begin{array}{l}\text { Only initial adult education for non-labour } \\
\text { market motives }\end{array}$ & 1 & 13 \\
\hline $\begin{array}{l}\text { All adult education undertaken primarily or } \\
\text { totally for labour market reasons }\end{array}$ & 30 & 10 \\
\hline \multicolumn{1}{|c}{ Total } & 35 & 29 \\
\hline
\end{tabular}

Most of the men but a minority of the women in this subset had undertaken all their adult education primarily for labour-market purposes. Women were later in using adult education to assist them in the labour market, but when they did so most of those in employment for instrumental reasons had taken labour-market-orientated courses at some stage, thus catching up with the men in this respect. It appears that adult education itself motivated some women to pursue labour market goals. Some of the answers women gave to the question 'Has adult education affected your ideas about yourself and the future' illustrate this:

Well, it's changed my total outlook in life. I mean, before I returned back to education and training I would have said to people, 'There's no point, it's no' meant for ordinary working-class people like ourselves, that's all for people who are really clever, or who can afford it, or things like that' ... It's given me an insight to what you can do (full-time vocational guidance counsellor).

It's widened my horizons ... Believing in myself and my capabilities ... developing my own potential and accepting responsibility ... I know I can choose what I want to do or choose what I don't want to do (full-time team coordinator).

The job that I've been doing, I've been doing it for seven years and I feel that I've gained enough experience to move on to another stage. (Adult education) has had an influence ... Yes, I would say that it's given me much more confidence, it definitely does (part-time senior medical receptionist, planning to take up the offer of a more demanding job).

Well, I think, really, you know ... about a career rather than a job, definitely ... and that is definitely possible. I see myself not just doing this but going on to do other things as well, even though I'm 44! (full-time social worker).

In summary, men employed for instrumental reasons (the majority) are more likely than women to expect or intend participation in adult education to benefit them in the labour market. A significant minority of the women were interested in learning for reasons other than labour market 'success'. 


\section{2 'Successful' economic outcomes $(n=53)$}

In all, 23 men and 30 women felt they had obtained labour market benefits, whether initially intended or not. These benefits are classified into five types in Table 3. The first two categories consist of reentering full-time or part-time employment after an absence from the labour market, or finding a job for the first time. The next two relate to getting a 'better' job or occupation - better, that is, according to the respondent's perception. Included here are interviewees who voluntarily gave up jobs in order to return to full-time education and then found jobs they valued more highly than their previous ones or which suited their personal circumstances better. Interviewees are divided into those who obtained full-time and those who obtained part-time work. The fifth, promotion, refers to an upward move in rank and income in the same organisation, probably (in these cases) with a 'permanent' employment contract. A further category comprises those who did not cite other benefits but who did mention performance enhancement.

Table 3. Reported labour market benefits obtained through adult education ( $\mathrm{n}=53$ )

\begin{tabular}{|l|c|c|}
\hline & Men & Women \\
\hline (Re)entered labour market (full-time) & 2 & 5 \\
\hline (Re)entered labour market (part-time) & 0 & 8 \\
\hline Got a better job (full-time) & 5 & 6 \\
\hline Got a better job (part-time) & 0 & 3 \\
\hline Promoted in current job & 10 & 6 \\
\hline Performance enhancement only* & 6 & 2 \\
\hline \multicolumn{1}{r|}{ Total } & 23 & 30 \\
\hline
\end{tabular}

* Many interviewees in the first five categories also have cited performance enhancement as an outcome.

In our sample, promotion was the biggest single outcome for men. All men and women in this category had had uninterrupted careers (apart from brief maternity leave in the case of two of the women) with the same employer, and were drawn from the group chosen by four large employers. The outcomes for women were more evenly spread among the different categories. 
That labour-market-orientated participation in adult education brings occupational benefits seems to be borne out by the majority of interviewees, at least in terms of their perceptions of 'success'; and unintended labour market outcomes also arose from participation in adult education in a number of cases. In addition, four of the women (but none of the men) who were unemployed at the time of interview felt that previous adult education had helped them to gain either full-time or part-time employment. They had become unemployed again, two as a result of redundancy, one because her husband took a job in another part of the country and one to have a baby.

\section{Subjective versus objective views of labour market 'success'}

Gooderham (1991) found that women in general spent substantially more time than men in education after returning to HSE but went on to acquire similar socioeconomic status (he did not gather data for income). What was important was acquiring post-compulsory qualifications. Ashenfelter \& Card (1985) found that women increased their earnings after the training programme substantially more than the men on the programme.

Labour market 'success' is, however, difficult to define, especially in the current climate of 'flexibility', which can see qualified, experienced people made redundant even when their firms are making profits. Obtaining a potentially permanent, well-paid job, or obtaining promotion within an organisation does not guarantee future employment; conversely, taking a contract job need not mean eventual unemployment. Any attempt at an 'objective' evaluation of success necessarily contains a subjective element (Bergman 1993), but net weekly income is a useful starting-point. Interviewees were asked to estimate their current income within a series of $£ 50$ bands, from less than $£ 50$ to over $£ 350$. This, however, has its limitations: in one organisation two of the interviewees earned more, through overtime, than someone higher in the hierarchy.

The employed women on average had lower incomes than the employed men, mainly because they were more likely to work part-time. The median income for men and women in full-time employment 
was the same (£250-299 net weekly), but three of the full-time female employees had lower incomes (£50-99) than any of the men. The women were predominantly, and to a far greater extent than the men, in public sector employment; and four of the men in the public sector were in relatively wellpaid police work, compared with only one of the women. This reflects Gooderham's (1991:207-8) finding that Norwegian women who completed their HSE tended to 'choose careers' (that is, find employment) in the comparatively low-paid public sector. The women in our sample were also more likely than men to be in low-status occupations (such as cleaning, caring, retail and clerical work). This finding is partly due to the nature and sources of the sample. The great majority (16 out of 21) of the men in this subset of our sample come from advantaged backgrounds (skilled working-class with small families or middle-class). A greater proportion of women (15 out of 32) came from disadvantaged backgrounds (poor unskilled working-class or skilled working-class families with more than four children), and a disproportionate number were drawn from community education and the Adults in Schools programme. The disparity in occupations does, however, reflect general trends.

Whatever their occupation or income, the subjective views of almost all the men and women concerning their jobs were positive. Nevertheless, one-third of the men had some reservations about their jobs, compared with less than ten per cent of the women. It is worth questioning why some of these women should be happy with the low-paid and low status jobs that their return to adult education had, to some extent, contributed to them having obtained. One reason might be amazement at having a job at all, combined with contentment to stay at the same level:

I just never expected to work again ... I like all of my job ... I've been asked to be the co-ordinator in here (but) I don't want to go to a higher level (full-time administrative assistant in an Unemployed Resource Centre, earning £50-99).

The fact that the women overall had less instrumental attitudes to paid work than men could also explain the satisfaction of some of those with low incomes. For example:

I like working with people, yeh, I like that ... Yes, I like the old, I like working - I miss the children - but I cannae have it both ways, so yeh, I like the job. Yeh I just like being there for them an' things like that, yep, that's the reason I'm ... (part-time home carer, earning £50-99). 
For others, getting a job at all after years of childcare was, in addition to pleasure in the work, satisfactory in itself:

I was getting fed-up with this routine, you know, wains, wains ... it's sorta opened up horizons for me, you know. Otherwise I would have went back into the same way I was before, I wouldn't even be working noo. I'd probably be sitting in the house you know. It comes to a stage where you realise that, there is you after a family and everything else, sort of thing (part-time senior adult education project worker, earning £100-149).

All but two of the women who felt they had benefited from adult education were enthusiastic about their jobs, and it is clear in a number of cases that non-monetary advantages were important. For example:

I'm thoroughly enjoying every part of my job. Like other people I get fed up counting certain things but my life is varied and ... I basically structure my own - I know what I've got to do and I structure it, which I enjoy (part-time researcher, earning £100-149).

I love my job. I think it's mainly because I created this job! so I feel very territorial about it. I'm very proud of it, proud of the achievements that we've made as far as disabled access is concerned, the money we've raised (part-time project director, earning £150-199).

Many of the interviewees, male and female, had no doubt that adult education had contributed to their

labour market improvement, irrespective of income or occupational status gained. For example:

My involvement in adult education has meant the furtherance of my career without a doubt ... it's given me a lot more confidence in my work life as well. I think that I can now ... without too much fear, talk to anyone at any level (male full-time manager, earning £250-299 net weekly).

It is through doing these short courses I've actually went and - I've furthered myself and went on to become a tutor ... also some money in my pocket. It's quite nice to have some extra spending money at times ... (female sessional tutor, earning less than $£ 50$ net weekly).

Those who reported that only their job performance had improved as a result of adult education were nevertheless satisfied with this; furthermore, a sense of enhanced job performance has potential labour market benefits (such as promotion or pay rise) and increases self-esteem and self-confidence:

I was more confident, I was more knowledgeable, I was more aware of my training needs, and of course the spinoff of that was that I realised that the people round about me could benefit from training, not particularly academic training but training in other parts of the job (male full-time supervisor).

Thus interviewees' subjective perceptions of their labour market progress were not always matched by 'objective' measures such as income and status; but the majority felt that returning to education had helped them in labour market terms. The women were, furthermore, at least as satisfied as the men by the outcomes, even though they did less well. They were, however, on average starting from a lower base in terms of prior qualifications and class background. Nevertheless, the men and women in full- 
time employment had the same median net weekly income, echoing Gooderham's and Ashenfelter \& Card's findings cited above.

\section{4 'Unsuccessful' economic outcomes}

Four of the men (all unemployed) and five of the women (three employed and two unemployed) said they had not benefited in occupational terms from their return to adult education. They gave different reasons for this. One man (unemployed, aged 46), felt that although his courses had given him a lot more confidence, the recession that prevented him getting a job. Similarly, a woman currently studying for an HNC said:

Well there's hundreds, thousands out there looking for jobs with even more [qualifications] ... I'm a wee bit more confident now. I'd like to maybe be more confident and think to myself that I'll get a job but I know myself that it's going to be very, very difficult ... Whereas now I can say, they're looking for somebody with that qualification, I've got that but the only thing I've no' got is the two years' experience that they're looking for so that downheartens you - you don't do it (female part-time hospital cleaner).

Disappointment was not always the reaction to 'failure'. One woman who had got a job while on the

Access course but was later made redundant was quite cheerful about it:

I was only here (on the Access course) about 3 months when I got started in the insurance place! ... I think it helped me getting a job in the insurance office, though the subjects I did here had nothing to do with the work. I think it just looked impressive, you know. The manager was easily impressed! (unemployed clerk).

Others felt that they had taken the wrong courses, even where they had enjoyed them. One had taken

Open University Community Education courses, which had made her more ambitious but also more frustrated:

although you got a certificate at the end o' it, you felt that it was a toy, because although I'd done all that, they're not regarded ... I went for a job to be a playgroup leader - my god, just a mother that helps and you'd have thought, well, with the experience of doing these courses in that age group - it didna matter, they were disregarded. 'But that was just Open University' ... I feel as if I could do better than what I am doing (part-time school cleaner).

Two older people, both unemployed, also felt they had chosen the wrong course:

I felt to try for English [O level] would have maybe helped me if I was looking for a job, you know ... (Did it?) No! No, I've never really worked full-time since I gave up my job. I've never really had a steady job since I gave up my job then (female unemployed typist, aged 49).

One man, who had abandoned his post-Access degree course for financial reasons, was more specific:

\footnotetext{
${ }^{2}$ Scots for 'children'
} 
My Access qualification is not recognised. It's a case of, the attitude in industry like, ONC, HNC, HNDs, they say, Well, we know what that is. I put down National Certificate Access, it means absolutely nothing ... it doesn't get past the first scrutiny when you're forming a job application (unemployed welder aged 53).

Three of the unemployed were graduates, including two who were still young. One had proceeded from the Access course to get a good honours degree in sociology, but was working in a part-time, temporary and ill-paid work scheme:

the reason why I spent four years, was to get a half-decent job, but if I was honest, I don't think it really helped in the present post (female aged 28).

A young male graduate with an ordinary degree in biology after a SWAP course was ambivalent about the value of adult education:

Well, right now I feel I've pissed away four years of my life, though that's not really true - for the moment that's how I feel ... (but) with my qualification, I'll get a job eventually - I'm not going to be unemployed for ever - it just feels like it at the moment ... If I was able to go there (university) knowing what I know now, I don't know if I would. I'd like to think I would ... but I don't know (aged 31, unemployed, doing voluntary work).

A 56 year old man, however, who had graduated as a mature student after a SWAP course perceived age as the reason for his unemployment:

I'm doing voluntary work - again, I can't get a job at all ... They're not interested. I think it's - age has something to do with it but, having said that, I just - I've never even had an interview, not even the courtesy of - it doesna matter, that's how it goes ... Literacy and numeracy - I'm a tutor ... (unemployed middle manager).

Certainly, men who lose their jobs when over 40 years of age have little chance of re-employment; yet one of the 'successes', a male skilled worker, after taking a degree for pleasure, started a second career teaching English in Spain at the age of 62.

One striking difference between those who succeeded in gaining employment and those who remained unemployed was that the former had been very clear about what kind of job they wanted after completing the course, whereas the latter tended to be less focused, giving answers such as 'Basically it was something to do' or 'Well, after a period of doing nothing you - you want to do something, you know'. Mikkonen (1996) and Tuijnman (1986) similarly found that there were greater labour market effects for those with a distinct occupational motive for schooling. 
As noted earlier, the hope that labour-market-orientated participation in adult education brings occupational benefits is borne out in the majority, but not all, cases. It is likely, though, that if the current job market eases, the two young graduates and the younger women will find employment. One lesson that can be learnt from this sample, albeit small, is the need for good vocational guidance and counselling for all adult learners but particularly for those on the margins of the labour market.

\section{The role of qualifications in labour market 'success'}

Rinne and Kivinen (1993) found that the great majority who benefited from 'second chance education' were those in higher-income groups and already qualified; more men than women reported that they had moved to more responsible jobs as a result of adult education; and women were 'a solid majority' on leisure-oriented courses. Tuijnman (1988:94) reported: 'There is some evidence to suggest that adult education indeed may provide a "second chance opportunity" for achieving upward career mobility' but found that initial education continued through a man's career to be a major determinant of occupational status. Adult education was most useful for men over 30 who already had qualifications. Fermlee (1988:36) found there seemed to be two paths to rapid labour market progress, 'staying in the job market and finding a better-paying job or returning to school for a reasonably long period before re-entering the labour force.' The latter course improved white women's occupational status and black women's wages. Even so, 70 per cent of the women in her study in clerical jobs remained in that occupation irrespective of the amount of time they took out for full-time education, and 'the effect of re-entry schooling on women's job rewards was relatively modest' (p. 41).

Choosing an appropriate course and gaining a qualification valued in the labour market, then, appear to be important. The higher the educational qualification taken, the greater the labour market outcomes generally accrued and the greater the chance of employment (Sly 1994), though any attempt to describe a hierarchy of qualifications necessarily involves rather arbitrary decisions. The qualifications gained by interviewees ranged from non-formally recognised certificates of attendance, 
through recognised 'vocational' and professional qualifications, to degrees and postgraduate qualifications.

Of the 74 interviewees, only one man and two women had no or only non-formally recognised qualifications. Two men and eight women had already obtained degrees as part of their continuous education; but a further seven men and eight women obtained degrees as a result of adult education. Three men and three women had obtained their highest vocational qualifications immediately after leaving school; but a further 26 obtained them through adult education. Two men and ten women had acquired or upgraded their school qualifications through adult education. In all, a remarkable 53 of the interviewees had gained their highest qualifications through adult education.

Proportionately more men than women had acquired higher vocational or academic qualifications as adults, whereas more women than men had gained only school qualifications, ranging from O levels to Certificate of Access Studies (equivalent to A levels). The distribution is different from that found by Munn \& MacDonald (1988:15), whose study found that 22 per cent had no initial qualifications (compared with only four per cent in this study) and 15 per cent had advanced qualifications (compared with 22 per cent in this study). The difference is to some extent due to part of the sample being chosen by employers and part from graduates who had done SWAP courses. A number of the successful men had gone straight into apprenticeships on leaving school at the statutory leaving age and stayed with the same employer for a long time.

The group reflects the expected trend that, on average, those with the highest qualifications and working full-time earned the highest incomes, irrespective of sex. The only unexpected feature is that on average higher vocational qualifications such as HNCs and professional qualifications earned interviewees as much as did degrees (median net weekly income of £275). All but two of the women with higher vocational qualifications gained as adults had, however, left school with at least one Higher or A level, and three had already had degrees. By and large, gaining academic or higher 
vocational qualifications generally paid off; it should be noted, however, that three of the unemployed were graduates, and lack of formal qualifications is not necessarily a barrier to high income in occupations such as the police force.

Another area explored was the number and type of courses taken. Table 4 summarises the relative number of courses, including employer-provided training, taken by men and women as adults.

Table 4. Number of courses taken, by sex $(n=74)$

\begin{tabular}{|l|c|c|c|c|}
\hline Number of courses & \multicolumn{2}{|c|}{ Men } & \multicolumn{2}{c|}{ Women } \\
\hline & No. & $\%$ & No. & $\%$ \\
\hline $1-3$ & 3 & 10 & 3 & 7 \\
\hline $4-7$ & 8 & 26 & 13 & 30 \\
\hline $8-10+$ & 20 & 64 & 27 & 63 \\
\hline & 31 & 100 & 43 & 100 \\
\hline
\end{tabular}

There is little significant difference in this sample between the relative number of courses taken by men and women, when employer-provided training is taken into account. When this is discounted, however, it was only women who had attended courses voluntarily year after year, whether Open University Community Education courses, Scotvec modules, O grades or Highers, or purely for pleasure. The provision of child care on many of these courses was an important factor. Only two men regularly took courses for pleasure, compared with six women. Table 5, which summarises the providers used, reveals more differences in the patterns of the men's and the women's adult education. 
Table 5. Adult education used by interviewees, by sex, in rank order of providers of education

\begin{tabular}{|l|c|c|c|c|c|}
\hline & \multicolumn{2}{|c|}{ Men } & \multicolumn{2}{c|}{ Women } & $\begin{array}{c}\text { Total } \\
\text { number }\end{array}$ \\
\hline Main providers: & Number & $\%$ & Number & $\%$ & \\
\hline Employer-provided training or CPD (1) & 30 & 97 & 34 & 79 & 64 \\
\hline College of Further Education & 30 & 97 & 30 & 70 & 60 \\
\hline University & 12 & 39 & 15 & 35 & 27 \\
\hline Adult Continuing Education Centre & 8 & 26 & 17 & 39 & 25 \\
\hline Community school & 5 & 16 & 17 & 39 & 22 \\
\hline Voluntary organisation & 3 & 10 & 18 & 42 & 21 \\
\hline WEA/ Extra-mural department & 6 & 19 & 15 & 35 & 21 \\
\hline Distance education/correspondence & 6 & 19 & 10 & 23 & 16 \\
course & & & & & \\
\hline Community Education & 1 & 3 & 10 & 23 & 11 \\
\hline Government training scheme & 3 & 10 & 2 & 5 & 5 \\
\hline
\end{tabular}

$1 \mathrm{CPD}=$ Continuing Profession Development

As Rinne and Kivenen (1993) found in Finland, the women were much less likely than the men to have had training or CPE provided by employers, partly because the men on the whole had more continuous careers than the women which has long made it difficult to compare socioeconomic outcomes affected by employer-provided training (Featherman \& Hauser 1976). Recent surveys, however, indicate that women are now likely to receive more job-related training than men (Gibbins 1994:392).

Men were more likely to have attended a college of further education, usually paid for by their employers, a trend confirmed by Tuckett \& Sargant (1996) and had, by and large concentrated on gaining valuable qualifications to acquire speedy labour market advantage. Those women who were in continuous employment, had prior qualifications and were focused on a career had similar patterns to men, taking fewer courses and higher qualifications.

Women were far more likely to have obtained their adult education through an Adult Continuing Education Centre, WEA or Extra-Mural Department, community school, College of Further 
Education, voluntary organisation or community education, a situation which is not new (see Woodley et al., 1987). Those with domestic responsibilities and poor educational backgrounds were far more constrained in what they could do and how quickly they could acquire a useful portfolio of Scotvec modules or school qualifications.

It appears that the women in this study differed from the men in two main ways: they had fewer opportunities for the 'fast track' to labour market advantage; and those who felt no need to advance their careers further were more likely to attend courses for pleasure.

It should be noted that, despite the labour market outcomes that most interviewees recorded, their most enthusiastic responses concerned the non-economic outcomes - and these were also reported by all but one of those been disappointed in their labour market aspirations. Calder (1993) also found that adults' criteria for 'successful' outcomes included confidence and enjoyment of the course as well as the usefulness of the qualification or skills/knowledge gained and the perception that the benefits had outweighed the costs in terms of the time and money invested and the effects of personal relationships. In general, adult education for the great majority in this study appears to have met its main objectives: 'improving the ability to live and work; aiding self-realisation; and encouraging healthy social relations and stimulating social action' (Savicevic 1990:104).

\section{Conclusion}

From the above discussion it is evident that the interviewees felt that adult education had assisted them (either directly or indirectly) in relation to labour market progress. It can therefore be argued that adult education is a valuable aid to social citizenship.

This does not mean that such social inclusion appeared in interviewees' descriptions of their reasons for returning to education. A majority hoped for and felt they had obtained positive labour market outcomes, and a significant number obtained unintended labour market outcomes. Women's relatively 
precarious relationship to the labour market did not appear adversely to affect feelings of inclusion: almost all were happy in their jobs and many felt adult education had improved them as individuals, whatever the course or courses they had taken.

There is, however, a caveat. The group was of overwhelmingly working-class background, but the majority already had at least some basic qualifications to help them in the labour market. A pessimistic reading might be that adult education is truly intrinsic to social citizenship, but that most of those who participate in it have already, at least potentially, the qualifications for such social inclusion.

\section{Bibliography}

ASHENFELTER, O. \& CARD, D. (1985) Using the longitudinal structure of earnings to estimate the effect of training programmes. Review of Economics and Statistics, 67:648-660.

BELL, R. (1996) The British adult education tradition: a re-examination, in R. Edwards et al., Boundaries of Adult Learning (London, Routledge/Open University), 152-168.

BERGMAN, E. (1993) Evaluation of adult education: necessary and possible. Life and Education in Finland, 2, 37-40.

BEVERIDGE, W. (1942) Social Insurance and Allied Services (London: HMSO, cmd 6404).

BEVERIDGE, W. (1944) Full Employment in a Free Society (London: George Allen \& Unwin).

CALDER, J. (1993) Disaffection and Diversity: overcoming barriers for adult learners (London: Falmer).

CLAYTON, P. AND SLOWEY, M. (1996) Toward the 'flexible' workforce? implications for gender and the education and training of adults. Scottish Journal of Adult and Continuing Education, 3(1), 45-62.

DUKE, C. (1992) What kind of adult education helps democracy? Adult Education and Development, $39,187-198$.

EUROPEAN COMMISSION (1997) Accomplishing Europe through Education and Training: Report by the study group on education and training, Directorate XXII (Luxembourg: Office for Official Publications of the European Communities). 
FARNES, N. C. (1993) A distance education contribution to a social strategy to combat poverty: Open University Community Education courses in Glasgow. International Journal of Lifelong Education, $\quad$ 12(3), 191-204.

FEATHERMAN, D. L. \& HAUSER, R. M. (1976) Sexual inequalities and socioeconomic chievement in the United States, 1962-1973. American Sociological Review, 41, 462-483.

FERMLEE, D. (1988) Returning to school and women's occupational attainment. Sociology of Education, 61, 29-41.

FIELDHOUSE, R. (1993) Have we been here before? A brief history of social purpose adult education. Adults Learning, 4(9), 242-3.

GELPI, E. (1994) Employment, Work and Citizenship (DECS/AE (94) 1) (Strasbourg: Council of Europe).

GIBBINS, C. (1994) Women and training - data from the Labour Force Survey. Employment Gazette, November 1994, 391-402.

GOODERHAM, P. (1991) Socioeconomic outcomes from adult education. Adult Education Quarterly, 41(4), 203-216.

HEANEY, T. (1992) When adult education stood for democracy. Adult Education Quarterly, 43(1), 51-59.

JANNE, H., DOMINICÉ, P. \& JAMES, W. (1980) Development of Adult Education: final report of the CDCC Project no. 3 ( Strasbourg: Council for Cultural Cooperation, Council of Europe).

LEVEY, M. \& MACKENZIE, K. (1996) The Class of '92: report on a longitudinal study of graduate destinations (Glasgow: Scottish Graduate Careers Partnership).

McGIVNEY, V. (1995) Skills, knowledge and economic outcomes: a pilot study of adult learners in Gloucestershire. Adults Learning, Feb 1995, 172-5.

MIKKONEN, I. (1995) Applying for and experiences in labour market training: motivation, expectations and realisation. Studies in Labour Policy, Number 95 (Ministry of Labour, Helsinki).

MUNN, P. \& MacDONALD, C. (1988) Adult Participation in Education and Training (Edinburgh: The Scottish Council for Research in Education).

PARK, A. (1994) Individual Commitment to Learning: Individuals' Attitudes. Report on the quantitative survey (Sheffield: Employment Department Research Series No. 32).

Office for National Statistics (1995). Regional Trends 1965-1995. CD-ROM (London: Office for National Statistics). 
RINNE, R. \& KIVINEN, O. (1993) Adult education, the Second Chance: fact and fiction. Scandinavian Journal of Educational Research, 37(2), 115-128.

ROGERS, A. (1992) Achievements and outcomes: evaluation, adult education and development. Adults Learning, 4(3), 69-72.

SAVICEVIC, D. M. (1992) Adult education and social change with special reference to the role of adult education in reducing unemployment, in Report of the Conference on Adult Education and Social Change, Belgrade 24-27 April 1990 (Strasbourg: Council of Europe).

SLY, F. (1994) Mothers in the labour market. Employment Gazette, November 1994, 403-413.

TUCKETT, A. \& SARGANT, N. (1996) Headline findings on lifelong learning from the NIACE/Gallup Survey 1996. Adults Learning, 7(9), 219-223.

TUIJNMAN, A. C. (1986) Recurrent Education and Socioeconomic Success: a theoretical and longitudinal analysis (Stockholm: Institute of International Education, University of Stockholm).

TUIJNMAN, A. C. (1988) Recurrent education and the occupational career, in K. Abrahamsson, ed., Implementing Recurrent Education in Sweden: on reform strategies of Swedish adult and higher education (Stockholm: NBE/UHA), 85-97.

WOODLEY, A., WAGNER, L., SLOWEY, M., HAMILTON, M. AND FULTON, O. (1987)

Choosing to Learn (Milton Keynes: SRHE/Open University Press).

8,083 words 